\title{
REMAJA YANG IDEAL ADALAH IDOLA SOSIALITA DAMBAAN ORANG TUA HARAPAN BANGSA DAN NEGARA
}

\author{
Achadyah Prabawati \\ ProgramStudi Ilmu AdministrasiNiaga \\ STIA Pembangunan Jember \\ *Email: achadyahprabawati@gmail.com
}

\begin{abstract}
ABSTRAK
Remaja adalah generasi penerus yang akan melanjutkan operasional pembangunann negara. Dipundak remaja negara akan berkembang dikemudian hari. Sehingga negara mengharapkan remaja Indonesia berjiwa unggul dan potensial. Remaja yang ideal adalah remaja idola sosialita. Remaja dambaan orang tua yang diharapkan Bangsa dan Negara, yaitu Indonesia.

Remaja dalam berkomunikasi harus tahu etika serta sopan santun. Remaja dalam bersosialisasi harus tahu tata krama. Bukan hanya tahu saja melainkan melaksanakan. Remaja dalam berfikir dan bertindak harus tahu batasan. Usia remaja adalah usia perubahan dari masa anak-anak menuju kedewasaan. Usia perubahan secara fisik maupun psikis. Dengan masa perubahan maka ada keinginan yang mendahului kemampuan. Apabila terjadi hal ini dan remaja tidak sadar maka akan terjadi kesalahan. Kesalahan yang terus menerus maka akan mengakibatkan permasalahan dalam hidup. Permasalahan yang tidak terkendali akan mengakibatkan pertumbuhan kenakalan remaja. Kenakalan remaja akan mengakibatkan mereka para remaja tidak dapat berfikir, berperilaku, mengambil keputusan yang benar. Remaja tersebut tidak dapat dipertanggung jawabkan dalam bersosialita. Sehingga remaja tersebut tidak dapat diunggulkan, tidak dapat diidolakan. Bahkan kenakalan remaja akan menghambat generasi penerus bangsa yang benar-benar diharapkan oleh bangsa dan negara.
\end{abstract}

Kata kunci : Etika, Sopan santun, Tata krama 


\section{Analisis Situasi}

Desa Jatimulya adalah desa yang mempuyai pondok pesantren dengan tingkat pendidikan SMP yang dinamakan SMP Plus Asrama Pembina Masyarakat (APM). Usia para santri dengan kisaran antara 12 tahun sampai dengan 17 tahun. Sehingga dapat dikatakan bahwa para santri termasuk dalam kelompok usia remaja.

Usia remaja merupakan masa peralihan yang disebut dengan masa transisi. Masa perubahan dari masa anak-anak menuju masa kedewasaan. Masa dengan kisaran usia antara 12 tahun sampai dengan 18 tahun. Masa pendidikan SLTP sampai dengan SLTA.

Masa remaja biasanya diawali dengan perilaku-perilaku yang berkaitan erat dengan masa pubertas. Dimana masa tersebut merupakan masa tumbuh- kembang yang dialami oleh semua manusia. Pertumbuhan dan perkembangan berlangsung dengan cepat. Pada perempuan pubertas ditandai dengan menstruasi pertama (menarche). Sedangkan pada laki-laki ditandai dengan mimpi basah.
Perilaku remaja terdiri dari perilaku kognitif, sosio-emosional, dan seksual. Perilaku kognitif merupakan suatu perilaku remaja yang ditandai dengan bagaimana pola berpikir dari remaja itu. Sedangkan perilaku sosio-emosional merupakan suatu perilaku yang erat kaitannya dengan emosi remaja dan bagaimana remaja berinteraksi dengan kehidupan sosialnya. Dan perilaku seksual yakni suatu perilaku yang berkaitan erat dengan keinginan untuk mengenal lawan jenis, sehingga mereka tumbuh keinginan untuk berpacaran.

Apalagi kini dikenal adanya masa pubertas dini pada remaja. Penyebab pubertas dini ialah anak yang melihat konten kekerasan, anak yang mengalami Malnutrisi, dan anak yang mengalami obesitas. Kondisi ini mempunyai efek memacu testis dan ovarium untuk memproduksi hormon Testoteron dan hormon Estrogen. Hormon ini diketahui sangat berperan dalam mengatur perkembangan seks.

Sehingga pada perkembangan remaja di masa pubertas diperlukan adanya pengontrolan diri dari orang 
tua. Pengontrolan mengenai masyarakat lingkungan dimana mereka berada.

$$
\text { Usia remaja merupakan }
$$
masa dimana mereka ingin mengetahui banyak hal yang belum mereka lihat dan mereka dengar. Masa dimana mereka ingin mencoba melakukan yang sebenarnya belum masanya untuk melakukan. Apakah kegiatan ini harus dilakukan oleh remaja ? Yang pasti jawabanya adalah "tidak". Agar terhindar dari petaka maka remaja harus tahu apa itu etika dan tata krama.

Pada masa remaja memang mereka telah memiliki keinginan untuk bebas. Bebas menentukan nasibnya sendiri. Remaja juga merasa semakin mampu dalam pengambilan keputusan. Hal ini perlu diwaspadai oleh orang tua. Hal yang ditakutkan apabila remaja melakukan pengambilan keputusan untuk melakukan hal yang terlarang yang membuat dirinya akan celaka.

Maka dari itu apabila remaja terarah dengan baik maka ia akan menjadi seorang individu yang memiliki rasa tanggung jawab. Tetapi kalau remaja yang tidak terbimbing maka bisa menjadi seorang yang tak memiliki masa depan dengan baik.

Dengan segala pengetahuannya maka remaja merasa punya kelebihan. Hal ini menimbulkan masa yang mempunyai keinginan bahwa dirinya akan dikenal oleh banyak orang. Kondisi ini berpengaruh terhadap timbulnya anggapan bahwa dirinya banyak diperhatikan oleh khalayak. Sehingga hal ini akan berkembang menjadi kemauan bahwa dirinya akan disanjung dan dipuja. Dan akhirnya membentuk suatu harapan bahwa dirinya adalah idola.

Para remaja tidak sadar bahwa "idola" hanya berlaku pada salah satu bidang saja. Mereka juga tidak sadar bahwa dikatakan "idola" itu masuk dibidang positif atau negatif. Yang pasti mereka "happy" bahwa dirinya adalah "idola".

Sebenarnya usia remaja adalah usia menuju kedewasaan. Usia Remaja adalah usia yang ideal untuk proses belajar, mengeksplorasi kondisional, dan mengembangkan diri. Sehingga tumbuh menjadi generasi muda yang 
dewasa, matang, berkualitas dan mandiri.

$$
\text { Penumbuhan pemikiran }
$$

bahwa "usia remaja adalah usia yang ideal untuk proses belajar demi pengembangan diri” perlu ditanamkan diawal masa remaja bukan pada menjelang dewasa. Artinya perlu diberikan pada siswa dengan pendidikan Madrasah Tsanawiyah, khususnya para santri di Pondok Pesantren Jatimulyo Kecamatan Jenggawah Kabupaten Jember.

\section{Landasan Teori}

Pada umumnya setiap individu atau organisasi dalam mencapai tujuan pasti mengalami beberapa kesulitan yang saling berkaitan antara satu dengan yang lainnya. Sudah tentu kesulitan akan dapat diatasi dengan cara memecahkan mencari solusinya. Untuk itu didalam menghadapi kesulitan, setiap individu atau organisasi harus mengidentifikasikan permasalahan kedalam beberapa bagian, sehingga memudahkan cara pemecahannya. Permasalahan ini menurut Suharsini Arikunto dibedakan atas tiga jenis, yaitu masalah untuk :

1. Mengetahui status dan mendeskripsikan fenomena;

2. Membandingkan dua fenomena atau lebih (problem komparasi);

3. Mencari hubungan antara dua fenomena.

Berdasarkan pendapat Suharsini Arikunto tersebut yang dikomparasikan dengan latar belakang diatas maka ruang lingkup yang menjadi batasan kegiatan pengabdian masyarakat ini adalah untuk mendiskripsikan semua hal yang ada sangkut pautnya dengan proses peningkatan kualitas remaja. Remaja yang menjadi generasi penerus bangsa yang unggul, bertanggung jawab dan mandiri serta berjiwa potensial.

\section{Identifikasi dan Perumusan} Masalah

Pada dasarnya tujuan pengabdian masyarakat ini adalah membentuk perilaku santri di sekolah SMP Plus Asrama Pembina Masyarakat sebagai masyarakat generasi penerus yang unggul, bertanggung jawab dan mandiri serta 
berjiwa potensial di Desa Jatimulyo Kecamatan Jenggawah Kabupaten Jember.

\section{Tujuan dan Manfaat Program}

Program pengabdian pada masyarakat yang dilakukan di SMP Plus Asrama Pembina Masyarakat Desa Jatimulyo Kecamatan Jenggawah Kabupaten Jember mempunyai kegunaan yaitu mengawali proses pembentukan kualitas generasi penerus yang unggul, bertanggung jawab dan mandiri serta berjiwa potensial dengan menanamkan :

1. Kerjasama Perti dengan dunia pendidikan remaja

2. Pelaksanaan etika dan tata krama dalam sosialita kehidupan

3. Membudayakan pola pemikiran yang wajar

4. Pemberian pengetahuan tentang siklus kehidupan

5. Peningkatan kualitas generasi penerus untuk mwnjadi unggul, bertanggung jawab dan mandiri serta berjiwa potensial

\section{Deskripsi Program}

Wilayah desa Jatimulyo yang disebelah utara dibatasi oleh desa Sruni Kecamatan Jenggawah, serta disebelah selatan adalah desa Sidodadi/ Pontang Kecamatan Tempurejo. Sementara wilayah timur dibatasi oleh PTP12 Glantangan Kecamatan Tempurejo, dan sebelah barat adalah desa Jatisari kecamatan Jenggawah. Wilayah desa Jatimulyo dekat dengan jalan raya yang menghubungkan kota Jember dengan tempat wisata Watu Ulo, pantai Papuma, pantai Love dan pantai Payangan sehingga mudah untuk dijangkau. Selain itu dekat dengan pelelangan ikan Puger sehigga hal ini akan mengundang banyak konsumen para wisatawan.

Wilayah desa Jatimulyo seluas 3.900 Ha dihuni oleh penduduk sejumlah 6.342 jiwa dengan 1778 kepala keluarga. Sebagian wilayah berupa lahan persawahan seluas 296 Ha yang dimiliki oleh 894 petani. Sementara penduduk yang lain adalah bekerja sebagai pedagang dan pegawai negeri sipil masing-masing sejumlah 15 orang dan 228 orang wiraswasta. 
Sehingga sisanya sejumlah 5.190 orang adalah mereka penduduk yang harus dibiayai. Mereka adalah para balita, para murid paud dan TK, para siswa SD/ SMP/ SMA \& SMK serta mahasiswa, juga para manula.

Dari jumlah penduduk sebagaimana diatas maka setiap orang yang bekerja membiayai 3 sampai 4 orang anggota keluarga. Sementara dengan 296 Ha lahan persawahan yang dimiliki oleh 894 petani maka menunjukkan rata-rata kepemilikan sawah seluas sepertiga hektar. Bila hasil panen 8 ton per hektar sawah dengan hasil keuntungan pertanian dengan kisaran Rp 5.600.000,- / Ha setiap empat bulan. Maka pendapatan untuk konsumsi dan saving setiap anggota keluarga petani adalah Rp30.900,per hari. Artinya petani desa Jatimulyo yang merupakan separuh dari jumlah penduduk desa Jatimulyo mempunyai tingkat ekonomi menengah.

Sementara para pegawai negeri sipil yang sejumlah 15 kepala keluarga tersebut yang mempunyai pendapatan minimal sesuai UMR yaitu Rp2.400.000,- per bulan.
Artinya anggota keluarga dari pegawai negeri sipil penduduk desa Jatimulyo termasuk ekonomi menengah karena setiap orang mempunyai konsumsi minimal sebesar Rp 20.000,- per hari. Berbeda dengan 15 pedagang dan 228 wiraswasta yang dengan kisaran 970 orang dari penduduk desa Jatimulyo dapat dipastikan berada dalam tingkat perekonomian menengah. Karena para pedagang dan para wiraswasta pasti punya penghasilan perhari sekitar diatas Rp50.000,- yang akan dinikmati oleh 4 orang dalam keluarga.

Studi kelayakan antisipasi kenakalan remaja untuk menjadikan remaja yang ideal, idola sosialita, dambaan orang tua, harapan bangsa dan negara, antara lain yaitu mempunyai tahapan :

1. Program silahturahmi kedunia pendidikan remaja

Kerjasama Perguruan Tinggi STIA Pembangunan Jember terhadap dunia pendidikan teraplikasi dalam program silahturahmi ke SMP Plus Asrama Pembina Masyarakat di Desa Jatimulyo Kecamatan Jenggawah Kabupaten Jember. Pada 
kegiatan tersebut tercatat bahwa SMP Plus Asrama Pembina Masyarakat mempunyai siswa kelas VII sampai dengan kelas IX dengan 68 siswa perempuan dan 54 siswa laki-laki.

Kegiatan para siswa sangat berkaitan dengan klasikal usianya. Usia remaja yang penuh dengan kebutuhan pribadi untuk diperhatikan untuk dikagumi untuk dipuja dan disayang. Mereka yang merasa terpenuhi tidak bermasalah, tetapi bagi mereka yang pendiam dan introvert maka tidak akan mendapatkan. Sehingga mengakibatkan perilaku yang beda. Mereka banyak termenung, berandaiandai, penuh harap dan akhirnya mereka tidak sadarkan diri. Selanjutnya yang mereka lakukan adalah tindakan lain-lain diluar kewajaran.

Perilaku diatas merupakan sisi negatif yang seharusnya tidak harus terjadi. Apabila mereka punya pola pikir yang positif dan wajar maka mereka akan menunjukkan potensi dirinya sehingga menarik perhatian teman bahkan masyarakat umum. Karena setiap manusia selalu memiliki kelebihan selain kekurangan pada dirinya.

Sebagai contoh kegiatan para remaja yang melakukan perbuatan yang tidak diperbolehkan. Remaja perempuan berpakaian seragam sekolah yang berboncengan tiga orang, tanpa menggunakan helm, melakukan balapan motor dengan para pembalap yang lengkap dengan costum balap. Kondisi ini tidak enak dipandang, artinya mereka melakukan tanpa etika. Mereka melakukan pelanggaran lalu lintas. Apalagi dilakukan dengan berpakaian seragam sekolah. Berarti mereka tidak menjaga nama baik sekolahnya. Dan lawannya adalah para pembalap yang menggunakan costum lengkap seorang pembalap. Wahana yang digunakan remaja perempuan tersebut bukan selayaknya untuk melakukan kegiatan itu. Mereka melakukan perbuatan ini hanyalah untuk mencari perhatian.

2. Penanaman etika dan tata krama kehidupan

Manusia lahir didunia langsung melakukan kegiatan yang disebut dengan belajar. Belajar bernafas 
dengan tangisan. Belajar proses pencernaan yang dipandu oleh ibu dengan minum air susu ibu hingga disuap makanan. Makanan yang diberikan pun bertahap mulai dari yang paling lunak hingga beraneka jenis makanan. Belajar bicara yang dipandu oleh orang tua bahkan siapa saja yang didekatnya dengan sapaan. Bahkan belajar bersosialisasi dengan mengharuskan menengok sipemanggil dan menjawab bila dipanggil. Belajar olah otak dengan mengajak bernyanyi dan berhitung. Usia balita adalah waktu pertumbuhan fisik maupun psikis. Pada usia inilah mulai pembentukan corak kepribadian anak. Anak diajarkan untuk bicara dengan sopan santun serta tahu etika. Anak diajarkan untuk berperilaku sesuai tata krama dan sopan terhadap yang lebih tua. Anak diajarkan bersikap baik serta jujur dalam bertindak. Anak diajarkan ikhlas dan menerima apa adanya atas pemberian orang tua.

3. Penanaman pola pemikiran yang wajar

Setelah masa pendidikan formal maka anak diajarkan untuk berfikir secara wajar sesuai teoritika.
Menyelesaikan soal sesuai dengan metode dan teori yang menjadi dasar pemikiran. Memberikan solusi apabila terjadi permasalahan serta memberikan kesimpulan sebagai dasar pedoman yang harus dilakukan bila terjadi permasalahan yang sama. Juga meminta saran pemikiran untuk mempersingkat penyelesaian dan pemberian solusi bila terjadi permasalahan.

Penyelesaian permasalahan bukan dengan adu bicara, adu tenaga, adu kekuatan raga. Masalah harus dibicarakan dengan tenang, dicari akar permasalahannya dan disusun solusinya. Bukan dilakukan dengan pertikaian dijalan raya pula. Hal ini sangat mengganggu keamanan warga setempat serta keamanan pengguna lalu lintas. Hal inilah maka sangat diperlukan adanya perilaku tata krama serta etika dan sopan santun bagi semua.

4. Pemberian pengetahuan tentang siklus kehidupan

Dengan kehidupan didunia maka terjadi daur siklus kehidupan. Dari nyamuk yang bertelur diair akan menetas menjadi jentik-jentik. Bila jentik-jentik sudah diam mengapung 
dipinggir bejana maka akan tumbuh sayap untuk terbang menjadi nyamuk. Dari kupu-kupu yang bertelur didaun akan menetas menjadi ulat. Ulat yang tua akan diam tumbuh selaput dan menjadi kepompong. Dan selanjutnya kepompong akan terobek dari dalam dan keluar kupu-kupu yang akan tumbuh dewasa. Katak bertelur diair dan menetas menjadi berudu. Berudu berenang yang bernafas dengan insang dan berenang dengan siripnya. Sirip tumbuh menjadi kaki dan siap untuk melompat menjadi kecebong. Kecebong melompat kedarat dan bernafas dengan paruparu menjadi katak. Akhirnya katak tumbuh dewasa. Semua itu siklus kehidupan binatang.

Berbeda dengan pertumbuhan manusia. Manusia lahir setelah pertumbuhan dalam rahim ibu selama sembilan bulan sepuluh hari. Tiga bulan pertama bayi manusia hanyabisa terlentang menyusu dan menangis. Usia empat bulan bayi baru belajar tengkurap, lima bulan baru dapat tengkurap dengan menyagga tubuh dengan tangannya serta terguling telentang lagi. Usia tujuh bulan baru belajar duduk, dan delapan bulan baru meraih untuk mengangkat badan dan berdiri dengan pegangan. Sembilan bulan baru belajar melangkah dengan pegangan. Sehingga usia setahun mulai belajar barjalan sendiri.

Manusia diusia balita hanya menerima pemberian orang tua. Diusia anak-anak mulai belajar mengambil yang disiapkan orang tua. Remaja adalah usia yang dipersiapkan untuk mandiri, belajar mengambil keputusan, dengan perubahan psikis serta hormon genetik yang semakin produktif. Kondisi ini yang merubah kondisi seseorang menjadi dewasa, dan siap untuk bereproduksi. Sebagai manusia yang agamis dan bermasyarakat maka untuk bereproduksi harus dilakukan secara hukum dengan pernikahan di Kantor Urusan Agama di Gereja atau di Kantor Catatan Sipil.

Produktifitas hormon genetik yang mendahului perkembangan fisik dibandingkan dengan psikis remaja mengakibatkan masa pubertas dini. Hormon genetik ini meliputi hormon Testoteron pada laki-laki dan 
hormon Estrogen pada perempuan. Mereka yang mengalami hal ini mempunyai keinginan selayaknya generasi diatasnya. Sehingga mereka banyak kebutuhan untuk ingin tahu, ingin mencoba, dan ingin merasakan. Tanpa sepengetahuan orang tua ataupun guru mereka akhirnya memuaskan kebutuhannya untuk mengetahui, mencoba, dan merasakan. Dengan pemenuhan kebutuhan yang seharusnya tidak boleh dilakukan, maka mereka timbul percaya diri bahwa mereka punya kelebihan dari remaja yang lain. Selanjutnya mereka lakukan berulang-ulang dan akhirnya kecanduan. Mereka tidak sadarkan diri bahwa perbuatannya adalah perbuatan kenakalan remaja. Yang mereka tahu adalah mereka lebih mengetahui, lebih diatas, dan menganggap dirinya adalah idola.

\section{Pengenalan tentang}

bagaimana kualitas generasi penerus yang unggul, bertanggung jawab dan mandiri serta berjiwa potensial.

Remaja sebagai generasi penerus bangsa Indonesia harus dapat berkarya secara mandiri. Maksudnya adalah membuat hasil karya sesuai dengan kemampuan pribadi. Hasil karya yang dapat digunakan oleh orang banyak dan mempunyai nilai ekonomis. Kondisi ini akan memberikan pendapatan ekonomi bagi si pemrakarya.

Remaja harus bertanggung jawab atas perilaku yang telah diperbuat. Maksudnya agar hasil karya yang digunakan oleh masyarakat harus menghasilkan kegunaan yang positif. Bukan membuat masyarakat menjadi bermasalah.

Untuk itu maka remaja harus unggul yang berjiwa potensial. Sehingga remaja itu harus mempunyai sifat keunggulan budi pekerti agar tidak menjadikan Indonesia semakin terpuruk, melainkan semakin jaya. Hal inilah yang disebut dengan berjiwa potensial.

Permasalahan yang harus dicari solusi pemecahnya antara lain adalah :

1. Cara mengantisipasi perilaku diri remaja

Remaja seharusnya berperilaku sesuai dengan menu kehidupannya. Apabila remaja menginginkan melakukan sesuatu yang seharusnya tidak dilakukan maka seharusnya 
jangan dilakukan. Karena suatu kegiatan ada pola etika. Manusia yang berperilaku wajar sesuai etika maka akan dihargai oleh masyarakat. Serta apabila remaja tidak punya etika pasti akan dicela masyarakat. Kegiatan inilah pangkal kenakalan remaja yang harus diberantas.

2. Cara memproses pembelajaran di masa remaja

Para remaja melakukan pembelajaran sesuai batas yang harus dipelajari. Tidak diperbolehkan untuk belajar sesuatu diluar menu kebutuhan remaja. Biasanya para remaja yang tidak terpenuhi kebutuhan psikis maupun fisik maka akan mencari komunitas yang sama. Sehingga mereka akan melampiaskan pemenuhan kebutuhannya diluar jalur.

3. Cara membuat pemikiran positif para remaja

Para remaja yang tidak terpenuhi kebutuhan psikis maupun fisik maka akan berfikir negatif. Maksudnya adalah berfikir untuk melakukan kegiatan terlarang. Bila kegiatan terlarang dilakukan oleh para remaja artinya remaja tersebut tergolong melakukan kenakalan remaja. Hal ini akan tidak terjadi bila para remaja mempunyai pemikiran baik buruknya bila ia melakukan hal tersebut. Mempunyai pemikiran bagaimana akibatnya bila ia melakukan hal tersebut.

4. Cara menyusun aplikasi konseptual remaja

Para remaja harus mempunyai tujuan kehidupan yang harus ia raih. Para remaja seharusnya sudah mulai berfikir mengenai tahapan yang harus dicapai dalam kehidupannya mendatang. Sehingga para remaja sudah mulai merencanakan kehidupan mendatang yang ia harapkan. Para remaja tidak boleh mengisi kehidupan dengan melakukan hal-hal yang tidak punya manfaat dikemudian hari.

5. Cara menyajikan perilaku remaja yang yang diharapkan

Remaja harus berperilaku sesuai dengan etika sopan santun terhadap sesama, apalagi terhadap yang berusia lebih tua, atau dengan golongan diatasnya. Cara bicara juga harus punya tata krama yang sebaiknya dilakukan. Hal ini untuk menanggulangi agar para remaja 
tersebut tergolong sebagai remaja nakal.

\section{Pelaksanaan Program}

Kegiatan Pengabdian Pada

Masyarakat. Kegiatan pengabdian pada masyarakat di SMP Plus Asrama Pembina Masyarakat Desa Jatimulya Kecamatan Jengawah Kabupaten Jember mempunyai tiga tahapan dalam operasionalnya.

1. Tahap pertama adalah persiapan

Merupakan tahapan dalam :

- mempersiapkan materi pengabdian

- melakukan pengurusan perijinan

- mempersiapan media dan kebutuhan administrasi

- mempersiapkan anggota peserta pengabdian

- mempersiapkan bahan untuk penggerak motivasi para audience.

2. Tahap kedua adalah pelaksanaan pengabdian masyarakat yang dibuka dengan sambutan pengenalan, pemaparan materi pengabdian masyarakat, diskusi permasalahan dan penyimpulan dan penutup. Adapaun isi dari pemaparan materi pengabdian pada masyarakat anatara lain adalah :

1) Bagaimana cara mengantisipasi perilaku diri remaja ? Etika \& tata krama kehidupan

2) Bagaimana cara memproses pembelajaran di masa remaja ? pola pemikiran yang wajar

3) Bagaimana cara membuat pemikiran positif para remaja ? tahu \& paham atas siklus kehidupan serta sadar diri atas kebutuhan pribadi

4) Bagaimana cara menyusun aplikasi konseptual remaja ? sosialisasi terhadap permasalahan lingkungan hidup manusia serta selalu problem solving

5) Bagaimana cara menyajikan perilaku remaja yang yang diharapkan ? remaja yang berkualitas, bertanggung jawab dan mandiri serta berjiwa potensial.

3. Tahap ketiga adalah pelaporan

- Pengumpulan dokumentasi yang berupa surat perijinan yang sudah ditanda-tangani dan daftar hadir peserta pengabdian-masyarakat 
- $\quad$ Penulisan laporan pengabdian pada masyarakat

- Pengadministrasian pada lembaga perguruan tinggi.

\section{Khalayak Sasaran}

Yang dimaksud dengan kenakalan remaja adalah perilaku para remaja yang tidak sepatutnya dilakukan oleh para remaja. Desa Jatimulyo terdapat sekelompok masyarakat yang mempunyai kegiatan pendidikan dengan nama SMP Plus Asrama Pembina Masyarakat. SMP yang bersiswakan para remaja. Agar para siswa tidak melakukan kegiatan kenakalan remaja maka dilakukan pengabdian pada masyarakat. Pengabdian masyarakat dengan judul "Remaja yang ideal adalah idola sosialita dambaan orang tua harapan bangsa dan negara" adalah suatu kegiatan yang mengajak masyarakat untuk melakukan kegiatan yang positif. Adapun yang dimaksud dengan kegiatan yang positif adalah kegiatan yang tidak bertentangan dengan yang harus dilakukan. Hal ini digunakan untuk menghindarkan diri agar remaja tidak melakukan kenakalan yang merupakan obyek dalam kegiatan pengabdian masyarakat ini.

Dengan pengabdian masyarakat ini maka disarankan bagi pembaca yang dekat dengan para remaja bahwa kenakalan remaja dilakukan oleh mereka yang tidak terpenuhi kebutuhan fisik serta psikisnya. Sehingga merekaharus didekati diajak komunikasi sehingga mereka tidak mengalami kefakuman komunikasi.

Sementara dengan tulisan ini yang banyak kekurangan maka mohon kritik dan saran atas kesempurnaan tulisan ini

\section{DAFTAR PUSTAKA}

Andi Mapiare (1988) Psikologi Remaja. Surabaya: Usaha Nasional.

Dwi Narwoko dan Bagong Suyanto (2007) Sosiologi Teks dan Terapan. Jakarta: Kencana Prenada media Group.

Eliasa, Eva Imania (2007). Kenakalan Remaja: Penyebab dan Solusinya. Makalah Disampaikan pada kegiatan PPL KKN SMAM Yogyakarta.

Gunarsa, Singgih D at al (1989). Psikologi Perkembangan: 
Anak dan Remaja. Jakarta: BPK. Gunung Mulia. Jakarta

Hurlock, E.B. (1991). Psikolgi Perkembangan Suatu Pendekatan Sepanjang Rentang Kehidupan (Terjemahan oleh Istiwidayanti dan Soedjarwo). Jakarta : Penerbit Erlangga.

Kartini Kartono. (1979) Phatologi Sosial Kenakalan Remaja, Jakarta: Rajawali.

Kartini Kartono,1986, Psikologi Sosial 2, Kenakalan Remaja, Rajawali, Jakarta.

Masngudin HMS, adalah peneliti pada Kenakalan Remaja Sebagai Perilaku Menyimpang Hubungannya Dengan Keberfungsian Sosial Keluarga. Puslitbang UKS, Badan Latbang Sosial Departemen Sosial RI. 11. January 2008, 19:34:39

Muhammad Ali dan Muhammad Asrori (2004) Psikologi Remaja Peserta Didik. Jakarta: Bumi Aksara.

Muhammad Al-Mighwar (2006) Psikologi Remaja. Bandung: Pustaka setia

Santrok, J. W. (2003) Adolescence (Perkembangan Remaja). Terjemahan. Jakarta: Penerbit Erlangga.

Sri Sumantri dan Siti Sundari (2004) Perkembangan Anak dan Remaja.Jakarta: Rineka Cipta
Sulis Styawan, 2007. Remaja dan perilaku menyimpang FMIPA Universitas Negeri Yogyakarta (uny). PT Antar Surya Jaya Surabaya. 2007.

Jurnal :

Laksmiwati, I. A. A. Transformasi Sosial dan Perilaku Reproduksi Remaja ; Available from URL:http://ejournal.unud.ac.i d.

Putri, R. L., Hadi, C. Bagaimana Lebih Memahami Seorang Diri Remaja ; Available from : URL:http://fpsi.unair.ac.id

Maria. U. Kenakalan remaja. 2009. Available from : URL:http://www.damandiri.o r.id.

Noviasari, E., Saputri, K. N., Masrurroh, I. N. Mata Pelajaran Pendidikan Reproduksi Remaja dalam Kurikulum SMP untuk Menghindarkan Remaja dari Tindak Aborsi Akibat Free Seks. 2010. Available from : URL:http://kemahasiswaan.u m.ac.id 